\title{
Possible fitness costs of high and low standard metabolic rates in larval herring Clupea harengus, as determined by otolith microstructure
}

\author{
Anders Bang ${ }^{1,2, *}$, Peter Grønkjær ${ }^{2}$, Arild Folkvord ${ }^{1}$ \\ ${ }^{1}$ Department of Biology, University of Bergen, PO Box 7800, 5020 Bergen, Norway \\ ${ }^{2}$ Department of Marine Ecology, Institute of Biological Sciences, University of Aarhus, Finlandsgade 14, \\ 8200 Aarhus N, Denmark
}

\begin{abstract}
In a laboratory experiment, we sought to identify effects of metabolic rate on the survival and growth of individual larvae of Clupea harengus L. The size of the otolith at hatch was used as a measure of standard metabolic rate (SMR) to test the hypotheses that (1) larvae with a low SMR survive longer than larvae with a high SMR during starvation, and (2) larvae with a high SMR grow faster than larvae with a low SMR during periods of high food availability. Herring larvae were reared in replicate tanks with either high, low or no food. Dead larvae were sampled twice daily and live larvae were sampled weekly. The longevity of the larvae was unrelated to their SMR in all treatments and, therefore, the first hypothesis was rejected. However, a positive correlation between otolith size-at-hatch and larval dry weight after hatch $(\mathrm{r}=0.48, \mathrm{df}=100, \mathrm{p}<0.001)$ suggested that the hypothesised negative effect of high SMR on longevity may be offset by higher energy reserves (i.e. more yolk) in these larvae. In both high-level food groups there was a significant association between sagitta growth and sagitta size-at-hatch $\left(\mathrm{H} 1, \chi^{2}=5.17, \mathrm{df}=1, \mathrm{p}=0.023 ; \mathrm{H} 2, \chi^{2}=4.75, \mathrm{df}=1, \mathrm{p}=0.029\right)$ and, therefore, the second hypothesis was supported. However, large otolith size-at-hatch was also observed in slow-growing larvae, hence a high SMR may be a prerequisite for fast growth, but does not necessarily result in fast growth.
\end{abstract}

KEY WORDS: Standard metabolic rate $\cdot$ Growth rate $\cdot$ Otolith size-at-hatch $\cdot$ Starvation resistance Predation resistance $\cdot$ Fitness costs $\cdot$ Atlantic herring larvae

Resale or republication not permitted without written consent of the publisher

\section{INTRODUCTION}

Larvae of highly fecund marine fishes suffer an extremely high natural mortality rate, such that any particular individual is very unlikely to survive to recruitment. The two most important processes governing larval survival are predation and starvation, which combined can cause a mortality rate of up to $50 \% \mathrm{~d}^{-1}$ for a larval cohort (Bailey \& Houde 1989). Starvation, predation and most of the other mortality mechanisms show a strong size-dependency (Miller et al. 1988), and mortality rates decrease rapidly with increasing size for marine fish species, and for the early life history stages in particular (McGurk 1986,
Bailey \& Houde 1989). Consequently, the growth rate of the individual larva and size-at-age as a regulator of early survival has received a great deal of attention.

In trying to identify why some larvae grow faster than others and supposedly survive better, the primary focus has been on exogenous factors such as temperature and food availability. While it is true that these factors are major determinants of larval growth rates, a larval cohort still shows considerable size-variability when reared in the same environment and given excess food (Metcalfe et al. 1992). This suggests that endogenous factors account for a substantial amount of variation in growth, something which is accentuated by the high heritability of growth rates (e.g. Purdom 1993). 
Fast growth requires high digestive and metabolic enzyme activities to allow for fast conversion of ingested prey to somatic tissue, and enzyme activity has been used as an indicator of nutritional condition for marine fish larvae (Ferron \& Leggett 1994). In support of this, Nathanailides \& Stickland (1996) found fast-growing Atlantic salmon to exhibit increased metabolic enzyme activity, indicating that fast growth is associated with a higher capacity for aerobic metabolism. Recently, differences in enzyme activities were shown to be influenced by maternal origin, indicating the existence of a predetermined baseline level of metabolic capacity (Patterson et al. 2004). Furthermore, Metcalfe et al. (1995) found that Atlantic salmon showing fast growth had higher standard metabolic rates, and it seems that standard metabolic rate (SMR) is a potential important endogenous regulator of larval growth rate.

Several studies support the notion that faster-growing larvae are favoured over slower-growing individuals (e.g. Meekan \& Fortier 1996, Hare \& Cowen 1997). However, under stressful environmental conditions there are possible fitness costs of having a high growth potential (Alvarez \& Nicieza 2005). Particularly, fastgrowing and high SMR larvae may be at a disadvantage in periods of nutrient stress (i.e. food-shortage) because of their higher energy demands (Arendt 1997). The energy reserves of fish larvae are very limited, and fast-growing larvae will use up their reserves faster, and die more quickly. A relatively low SMR will give a lower growth capacity but also a smaller energy-demand, and these larvae may be more competitive and survive longer in periods of food shortage than high SMR individuals. So, depending on the feeding conditions, there are both advantages and disadvantages of a high growth potential, and there may be a trade-off between starvation resistance and predation resistance. In an environment such as the sea, with unpredictable and patchy predator and prey densities, this would explain the occurrence of high variation in metabolic and growth rates (Chambers et al. 1988, Bang et al. 2004).

To examine this potential trade-off, we tested 2 hypotheses: (1) that larvae with a low SMR survive longer than larvae with a high SMR during starvation, and (2) that larvae with a high SMR grow faster than larvae with a low SMR during periods of high food availability. Testing these hypotheses has hitherto been hindered by the inability to identify individuals with low or high baseline growth, or its corollary metabolic rate, and the lack of means to track a sufficient number through time. Recently, otolith size-at-hatch has been used as a proxy for the predetermined standard metabolic rate (SMR) of the embryo (Bang et al. 2004, Bang \& Grønkjær 2005). Bochdansky et al. (2005) used this proxy to show that, when starved, radiated shanny Ulvaria subbifurcata larvae with a relatively small otolith size-at-hatch survived longer than conspecifics with a relatively large otolith size-at-hatch. Unfortunately, Bochansky et al. (2005) did not test for a potential trade-off with growth rate. In the present study, we examined the relationship between the SMR of embryos of Atlantic herring Clupea harengus (as approximated by their otolith size-at-hatch) and (1) the subsequent time to death, and (2) the growth of the larvae exposed to different prey levels.

\section{MATERIALS AND METHODS}

Experimental set-up. Ripe Norwegian autumnspawning herring Clupea harengus L. were caught on

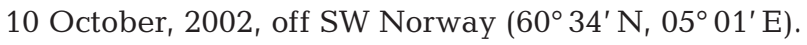
Parental fish were chosen to create a large range in sizes and ages (Table 1). Eggs from 3 females were fertilised separately with pooled sperm from 6 males by stripping gametes onto plastic sheets, and were then incubated in the laboratory at $12.0 \pm 0.1^{\circ} \mathrm{C}$ in 2 incubation tanks $(215 \times 40 \mathrm{~cm}, 10 \mathrm{~cm}$ depth). Tanks were supplied with running sea water at a rate of $51 \mathrm{~min}^{-1}$. One day before hatching, the eggs were subjected to an immersion marking with alizarin red S (100 $\mathrm{mg} \mathrm{l}^{-1}$ for $12 \mathrm{~h}$ ). Just after hatching, 450 larvae (150 larvae from each female) were transferred to each of six 1801 green fibreglass rearing tanks, 2 tanks with a nominal prey concentration of 600 prey larva ${ }^{-1}(\sim 3.3$ prey larva ${ }^{-1} \mathrm{l}^{-1}=$ high growth, $\mathrm{H} 1$ and H2), 2 tanks with a nominal prey concentration of 15 prey larva ${ }^{-1}$ $\left(\sim 0.08\right.$ prey larva ${ }^{-1} \mathrm{l}^{-1}=$ low growth, L1 and L2), and 2 tanks without prey (starvation, S1 and S2). These prey concentrations were chosen based on previous studies of food-limited growth of herring larvae in the laboratory. One group of 100 larvae from each female were transferred to 51 buckets and kept without food

Table 1. Clupea harengus. Data on parental fish used in the experiment. Total length was measured to the nearest $0.1 \mathrm{~cm}$. Weight $=$ wet weight before stripping; GSI = gonadosomatic index. Fish were aged by counting annual zones in the otoliths

\begin{tabular}{|lcccc|}
\hline Fish & $\begin{array}{c}\text { Total length } \\
(\mathrm{cm})\end{array}$ & $\begin{array}{c}\text { Weight } \\
(\mathrm{g})\end{array}$ & $\begin{array}{c}\text { GSI } \\
(\%)\end{array}$ & $\begin{array}{c}\text { Age } \\
(\mathrm{yr})\end{array}$ \\
\hline Female 1 & 33.2 & 493.1 & 9.9 & 6 \\
Female 2 & 30.3 & 409.8 & 7.5 & 7 \\
Female 3 & 29.4 & 313.1 & 9.3 & 3 \\
Male 1 & 36.1 & 481.4 & & 8 \\
Male 2 & 35.1 & 403.7 & & 5 \\
Male 3 & 33.1 & 321.2 & & 6 \\
Male 4 & 32.9 & 346.7 & & 3 \\
Male 5 & 30.8 & 292.4 & & 3 \\
Male 6 & 30.3 & 288.6 & & 3 \\
\hline
\end{tabular}


as viability controls. These controls showed no difference in larval survival among females and experimental data was subsequently pooled across females.

From Day 3 after hatch onwards, larvae were fed live natural zooplankton (mainly nauplii and copepods) filtered to the size range 80 to $250 \mu \mathrm{m}$. Prey concentrations in the tanks were assessed by counting five $200 \mathrm{ml}$ pipette samples from different positions in each tank, so that a total of at least 50 prey items were counted from each tank. Prey was added daily to attain the nominal treatment prey concentration. In addition, $1 \mathrm{l}$ of algae (Isochrysis galbana, 3 to $4 \times 10^{6} \mathrm{ml}^{-1}$; and Rhodomonas baltica, 1 to $1.5 \times 10^{6} \mathrm{ml}^{-1}$ ) was added daily to each tank. Continuous aeration was supplied to mix the water and ensure an oxygen saturation of $>90 \%$ at all times. During sampling, about $10 \%$ of the water in each tank was replaced daily. Incoming water was taken from $90 \mathrm{~m}$ depth, and salinity averaged 33.9 psu during the experiment. Temperature was $11.8 \pm 0.2^{\circ} \mathrm{C}$ (range) in all tanks and in the buckets. The light regime was kept constant at 12:12 h light:dark and applied by a single $20 \mathrm{~W}$ halogen bulb over each tank. White plexiglass lids on top of each tank provided diffuse light and reduced light intensity to an average of $400 \mathrm{~lx}$ at the water surface (range 365 to 496 lx).

From Day 1, dead larvae were sampled twice daily by gently siphoning the bottom of all the tanks, however only larvae collected from Day 11 onwards were analysed. This was just before the onset of significant mortality and larvae dying prior to this were assumed to have done so because of events unrelated to starvation (e.g. malformation). From each tank a maximum of 20 dead larvae were analysed per day. On days when more than 20 larvae died, a random subsample was taken. In addition, starting on Day 4, 20 living larvae were sampled weekly from each tank to monitor larval growth of the different groups. Photographs of these growth control larvae were taken under a dissecting microscope for later measurements of standard length (SL). All sampled larvae were then stored in individually labelled Eppendorf tubes at $-80^{\circ} \mathrm{C}$ until further analyses. After thawing and drying for $24 \mathrm{~h}$ at $60^{\circ} \mathrm{C}$, the dry weight (DW) of the larvae from the growth control was recorded to the nearest $\mu \mathrm{g}$ on a Sartorius Micro M3P microbalance.

Otolith analyses. Both the right and left sagitta were removed from individual larvae under a dissecting microscope at $60 \times$ magnification using a polarised light source and fine insect needles mounted on handles. The unpolished otoliths were embedded in thermoplastic resin (Crystalbond ${ }^{\mathrm{TM}}$ 509), which was then reheated and the otoliths turned so analyses could be conducted on the sagittal plane. Furthermore, to avoid optical distortion, excess resin was removed so that only a thin layer covered the otoliths. All otoliths were essentially spherical, but a few with 2 or more cores or of irregular shape were omitted from further analyses. Marking success was high and only 2 otoliths failed to show an alizarin mark. The right sagitta from 445 larvae (growth controls) and 869 larvae (dead individuals) was measured. Digital pictures of the otoliths were taken at $400 \times$ magnification using an Olympus fluorescence microscope system equipped with an Olympus DP50 high-resolution video camera. The alizarin mark area and the total otolith area were measured manually on-screen with the image analysis software ImageTool 3.0 (UTHSCSA). Otolith area is a better estimate of otolith size than unidimensional measures (Meekan et al. 1998). Measurement error was assessed by remeasuring the total sagitta area and alizarin mark area of 10 otoliths from each of the 2 high prey level growth controls from Days 11, 18 and 25 (a total of 60 otoliths and 120 measurements). No significant differences were found between any of the 6 groups of otoliths and their remeasurements (paired $t$-tests, $\mathrm{df}=9, \mathrm{p} \gg 0.05$ ). Coefficients of variation for otolith area and alizarin mark area were low (1.0 to 1.5 and 1.0 to $1.6 \%$, respectively) and no trend was observed in the $\mathrm{CV} \%$ with respect to age.

Statistical analyses. Statistical tests were performed using the statistical package SPSS for Windows. Total survival and average daily survival were estimated with an exponential model assuming that sampled larvae had been alive until the day of sampling. Missing larvae were not considered part of the initial population. The majority of missing larvae probably died prior to sampling at Day 11. No larvae could escape the experimental tanks, as no flowing water change was carried out, and older dead larvae were more easily found because of their larger size. Consequently, the interpretations of the results are not likely to be affected.

Based on the weekly growth samples of the herring larvae, mean daily growth rate in standard length was calculated as $\left(L_{2}-L_{1}\right) \times\left(t_{2}-t_{1}\right)^{-1}$, where $L$ is the mean standard length at Time Periods $t_{1}$ and $t_{2}(\mathrm{~d})$, respectively. Mean daily growth rates for dry weight and sagitta area were calculated as specific growth rates, SGR $\left(\% \mathrm{~d}^{-1}\right)=100 \times g$, where $g=\left(\ln \left(S_{2}\right)-\ln \left(S_{1}\right)\right) \times$ $\left(t_{2}-t_{1}\right)^{-1}$, and $S=$ mean dry weight or mean sagitta area on Days $t_{1}$ and $t_{2}$, respectively.

\section{RESULTS}

\section{Survival and feeding}

As expected, survival was dramatically different among the feeding levels (Fig. 1). Generally, non-fed larvae (control, S1 and S2) exhausted their yolk sac around Day 5 ; on Day 12 they showed a sharp increase in mortality; by Day 14 they had suffered 50\% mortality, and 


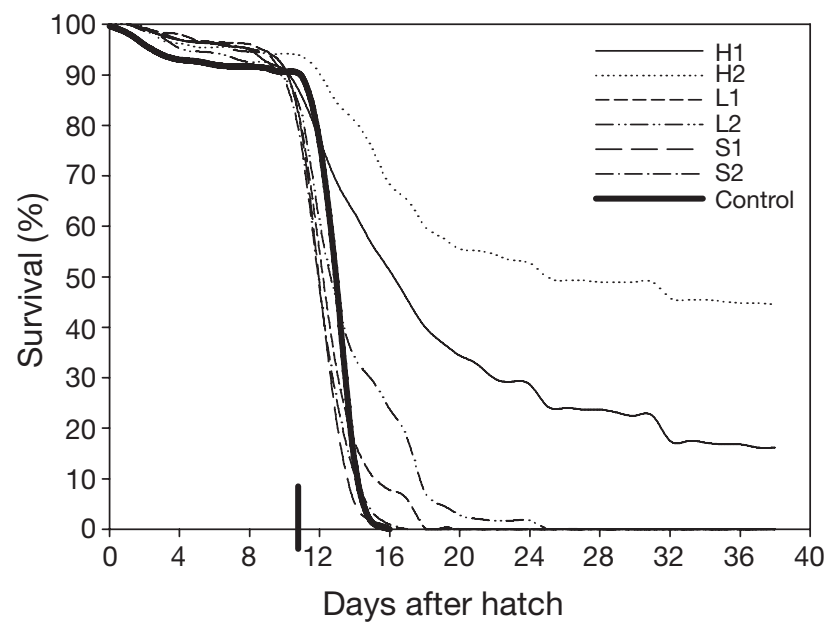

Fig. 1. Clupea harengus. Survival percentages from Day 2 until end of experiment on Day 39 of the different larval groups $\left(\mathrm{H}=\right.$ high-level food, 600 prey larva ${ }^{-1} ; \mathrm{L}=$ low-level food, 15 prey larva ${ }^{-1} ; \mathrm{S}=$ starvation). Control = mean survival for the viability groups. Missing larvae were not considered part of initial population and sampled larvae were considered as surviving until day of sampling. Vertical bar on $x$-axis indicates start of sampling of dead larvae (Day 11)

none survived beyond Day 17. Survival of larvae from the low-level feeding groups (L1 and L2) was similar to that of the starved groups, but with $100 \%$ mortality occurring on Days 20 and 26, respectively. Only larvae from the high-level feeding groups ( $\mathrm{H} 1$ and $\mathrm{H} 2$ ) survived until the termination of the experiment, with 16 and $44 \%$ survival on Day 39, respectively. The estimated average daily mortality rates were 6.3 and $3.4 \% \mathrm{~d}^{-1}$ for the $\mathrm{H} 1$ and H2 groups, respectively. Despite careful sampling of dead larvae twice daily, on average $9.5 \%$ of the larvae in the tanks could not be accounted for by the end of the experiment. However, missing larvae showed no trend across feeding groups $(1,17,3,19,10$ and $7 \%$ for $\mathrm{S} 1$, $\mathrm{S} 2, \mathrm{~L} 1, \mathrm{~L} 2, \mathrm{H} 1$ and $\mathrm{H} 2$, respectively).

The average larva from the low-level feeding groups never initiated feeding, whereas larvae from the highlevel feeding groups began feeding immediately (Fig. 2). These high-level fed larvae initially consumed about 50 prey larva ${ }^{-1} \mathrm{~d}^{-1}\left(0.07\right.$ prey larva ${ }^{-1} \mathrm{~min}^{-1}$; daylight feeding time) during the first week. Larvae in the $\mathrm{H} 2$ group then increased their feeding to a maximum of about 400 prey larva ${ }^{-1} \mathrm{~d}^{-1}$ or 0.56 prey larva ${ }^{-1} \mathrm{~min}^{-1}$ at the end of the experiment, while the H1 larval group remained at a lower level of about 100 prey larva ${ }^{-1} \mathrm{~d}^{-1}$ (0.14 prey larva $\left.{ }^{-1} \mathrm{~min}^{-1}\right)$.

\section{Growth}

Growth in standard length, dry weight, and sagitta area varied among feeding groups, with the largest dif-

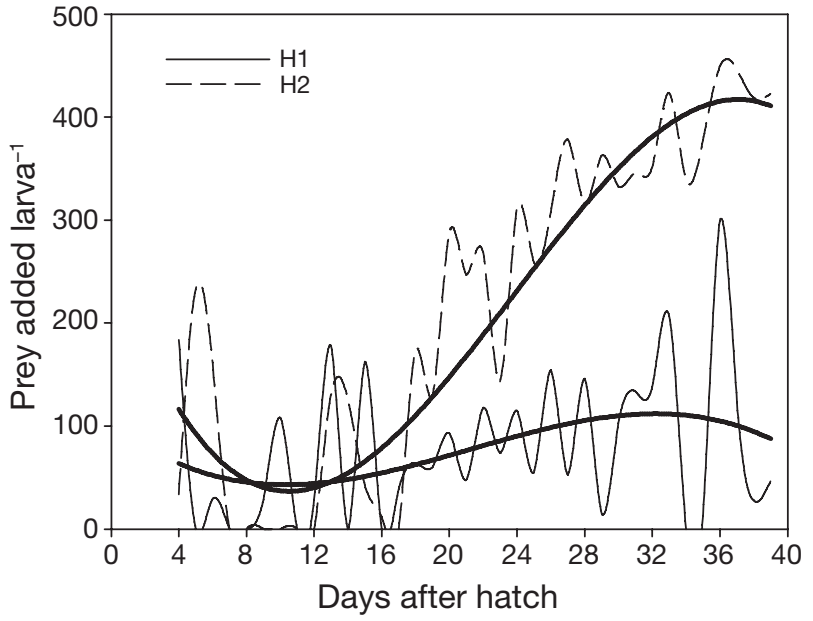

Fig. 2. Clupea harengus. Number of added zooplankton prey larva $^{-1}$ for the high-level feeding groups. Low-level feeding groups not shown as no significant amount of prey was added. Feeding ratios are not corrected for missing larvae. Third-degree polynomial regression curves (heavy lines) included to show general trends in data

ferences observed in dry weight growth and sagitta area growth (Fig. 3). Initially, growth rates in length were slow with no major differences among the feeding groups (Fig. 3). At the end of the experiment, larvae from the high-level feeding groups ( $\mathrm{H} 1$ and $\mathrm{H} 2$ ) had increased their growth but, overall, the length growth rate remained constant (around $0.15 \mathrm{~mm} \mathrm{~d}^{-1}$ ). All groups initially lost weight; larvae from the high-level feeding groups ( $\mathrm{H} 1$ and $\mathrm{H} 2$ ) at a slower rate than larvae from the low-level feeding (L1 and L2) and starvation (S1 and S2) groups. In the second week, larvae from the low-level feeding groups still lost weight, while larvae from the high-level feeding groups gained weight, with larvae in the H2 group gaining weight faster than larvae in the H1 group. Sagitta growth initially showed large variation with no consistent trend among groups. Sagitta growth then dropped during the second week in all groups except H2. Sagitta growth subsequently increased for both high-level feeding groups, with $\mathrm{H} 2$ larvae always growing faster than H1 larvae (Fig. 3). At the end of the experiment, the large difference in growth between the 2 high-level feeding groups resulted in larvae from the $\mathrm{H} 2$ group being on average $19 \%$ longer, $128 \%$ heavier and having $123 \%$ larger otoliths than larvae from the H1 group; no larvae from the starvation or low-level feeding groups survived to the end of the experiment.

\section{Starvation resistance and size relations}

There was no relation between time of death and the size of the sagitta at hatch (estimated by the alizarin 

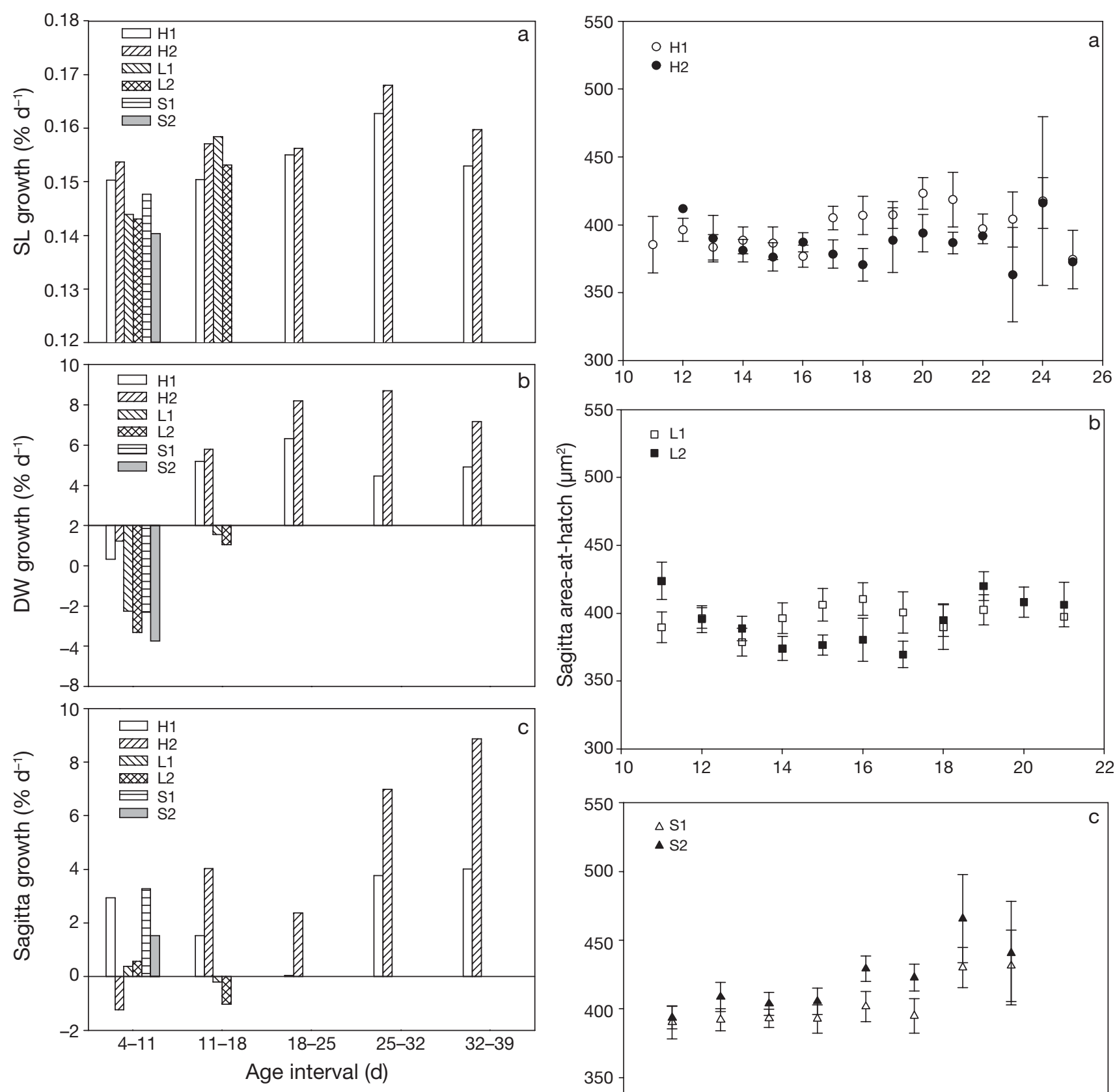

Fig. 3. Clupea harengus. Mean growth rates of larvae during experiment. (a) Standard length, SL; (b) dry weight, DW; (c) sagitta area
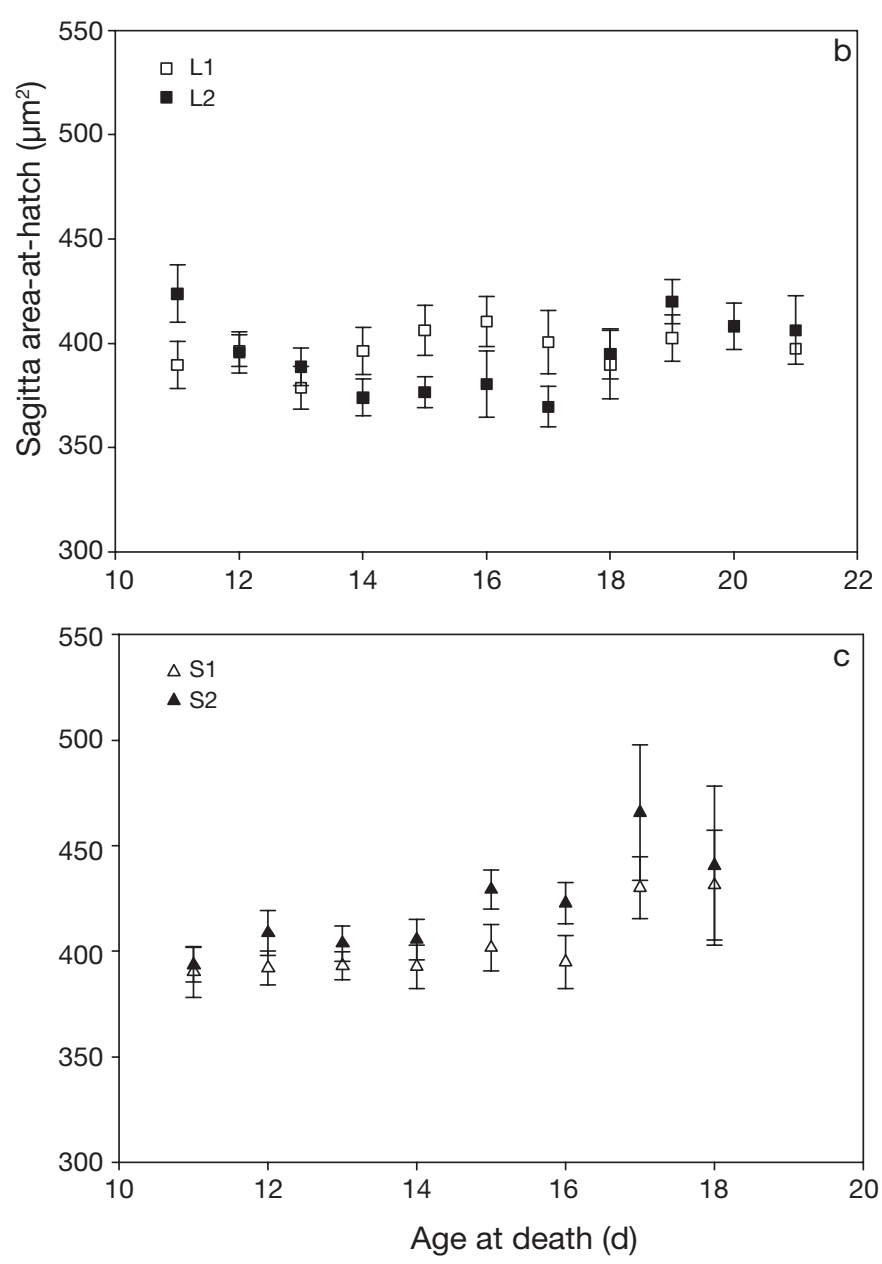

mark area) for any of the feeding groups (Pearson product-moment correlations, $\mathrm{r}=0.044$ to 0.163 , $\mathrm{df}=$ 109 to 181, p > 0.05) (Fig. 4). Generally, there was a large spread in the size of the hatch-mark at all sampling times and both larvae with relatively large and small otoliths at hatch survived equally well. Thus, we reject our first hypothesis: larvae with small otoliths at hatch (a proxy for low SMR) did not survive longer than larvae with larger otoliths at hatch.

Fig. 4. Clupea harengus. Mean ( \pm SE) sagitta size-at-hatch (alizarin mark area) as a function of time of death for individual larvae in the different feeding groups. Note different scales of $x$-axes

However, there was a significant positive correlation between sagitta size-at-hatch and dry weight of $4 \mathrm{~d}$ old larvae (Pearson product-moment correlation, $\mathrm{r}=0.48$, $\mathrm{df}=100, \mathrm{p}<0.001)$, but sagitta size only explained $23 \%$ of the variation in dry weight (Fig. 5). This sug- 


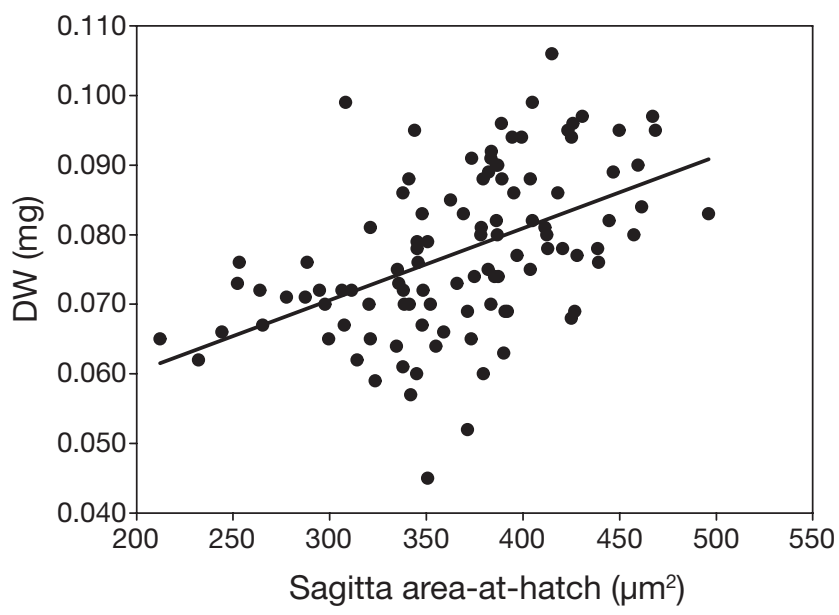

Fig. 5. Clupea harengus. Dry weight of $4 \mathrm{~d}$ old larvae vs. sagitta size-at-hatch $(\mathrm{n}=101)$. Linear least-squares regression model was fitted to data $\left(y=0.000105 x+0.0389, r^{2}=0.23\right)$

gests that the amount of maternal contribution in the form of yolk may have influenced larval survival.

\section{Growth of survivors}

Only larvae from the 2 high-level feeding groups were used in the analyses of growth and survival since these were the only larvae that survived to the end of the experiment. An overall regression of sagitta areaon-length of the larvae from all the days combined was highly significant and given by the equation: log Sagitta area $=0.0922 \mathrm{SL}+1.719, \mathrm{n}=207, \mathrm{r}^{2}=0.81$. The sagitta area was thus considered a suitable proxy for larval size.

There was a positive relation between sagitta sizeat-hatch and subsequent growth (Fig. 6), but the strength of this relationship varied across time and no single type of regression provided a good fit to the entire data set (e.g. linear, $0.001<\mathrm{r}^{2}<0.54$; power, $0.001<\mathrm{r}^{2}<0.52$ ). There was a clear tendency for accelerated growth to be predominantly shown by larvae with large sagitta at hatch, while reduced growth was shown by larvae with both large and small sagitta at hatch. To emphasise this pattern, larvae were grouped across sampling dates into 4 quadrants divided by mean sagitta size-at-hatch and mean sagitta growth, and the respective quadrants for each sampling date were then pooled (Fig. 7). For both larval groups there was a significant association between sagitta growth and sagitta size-at-hatch $\left(\mathrm{H} 1, \chi^{2}=5.17\right.$, df $=1, \mathrm{p}=$ 0.023 ; $22, \chi^{2}=4.75$, df $=1, \mathrm{p}=0.029$ ) so that significantly fewer larvae with a small sagitta size-at-hatch showed accelerated growth. However, as with the regression analyses, a coefficient of association indicated that this relationship was not perfect (H1,
Kendall's tau-b =0.242; H2, Kendall's tau-b = 0.221). Thus, our results provide support for our second hypothesis: larvae with large otoliths at hatch (a proxy for high SMR) grow faster than larvae with low SMR during periods of high food availability.

\section{DISCUSSION}

\section{Survival and start-feeding}

The general mortality pattern was typical of experimental populations (Fig. 1). Control and starvation groups suffered $50 \%$ mortality around Day 14, which compares with a similar study on autumn-spawning Atlantic herring by Solbakken (2001) and with Atlantic herring larvae at $12^{\circ} \mathrm{C}$ in general (Blaxter \& Hempel 1966). However, the mortality rates of the low-level and high-level feeding groups were surprisingly high compared to other studies. Solbakken (2001) reported mortality rates of 1.4 to 1.9 and 0.5 to $0.6 \% \mathrm{~d}^{-1}$ for lowlevel and high-level feeding groups, respectively, at $10^{\circ} \mathrm{C}$. Likewise, Johannesen et al. (2000) reported mean daily mortality rates of 1.5 to 2.4 and $<0.4 \% \mathrm{~d}^{-1}$, respectively, at $8^{\circ} \mathrm{C}$.

There are several possible explanations for the high mortality observed in the present study. Chemical marking with alizarin Red $\mathrm{S}$ has been shown to adversely affect survival of cod eggs and larvae in some instances (Blom et al. 1994), probably due to stress in connection with the marking event. However, the main mortality in this experiment occurred well after marking (Fig. 1). Prey levels could have been insufficient to initiate a successful start-feeding or sustain normal growth rates. However, similar levels were used in the studies by Folkvord et al. (2000) and Solbakken (2001), where no significant start-feeding problems were encountered. Furthermore, the prey sizes covered the range normally required by earlyfeeding herring larvae and light levels were well above what is needed to ensure a complete incidence of feeding (Blaxter \& Hunter 1982). Finally, the stocking concentration of 2.5 larvae $1^{-1}$ was low compared to maximum concentrations recommended for early stage clupeid larvae (5 to 10 larvae $\mathrm{l}^{-1}$ ) (Blaxter \& Hunter 1982). Together with the high nominal prey levels, this makes it unlikely that crowding effects were the cause of the high larval mortality.

The present study was carried out at $12^{\circ} \mathrm{C}$, which is a few degrees warmer than the natural conditions experienced by herring larvae from autumn-spawning North Sea stocks during first-feeding (Johannesen et al. 2000). At the same time, the newly hatched larvae in this study had a very low average starting dry weight of $86 \mu \mathrm{g}$ compared to values of 136 and $169 \mu \mathrm{g}$ 

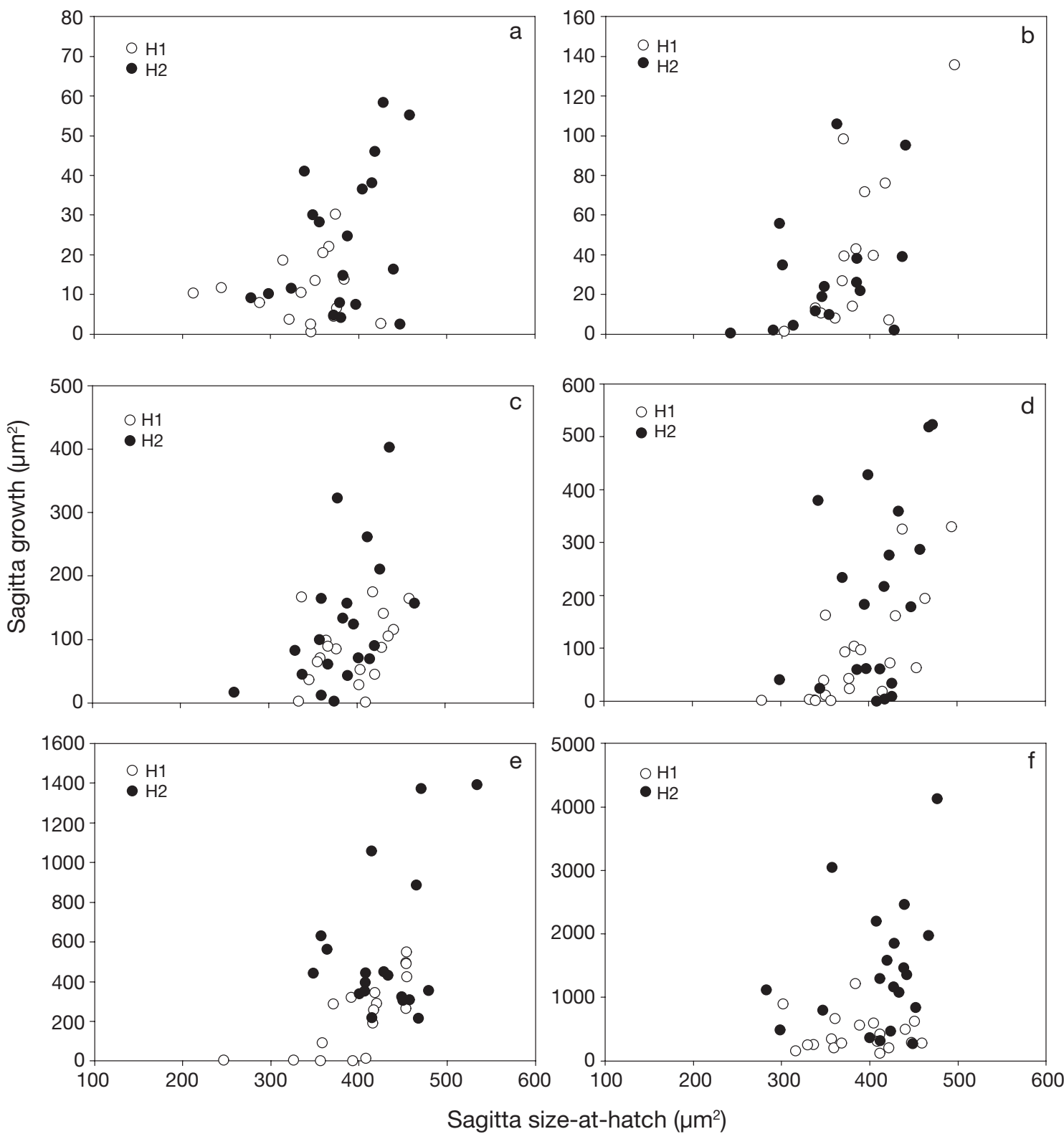

Fig. 6. Clupea harengus. Sagitta growth as a function of sagitta size-at-hatch for individual larva from the 2 high-level feeding groups on (a) Day 4, (b) Day 11, (c) Day 18, (d) Day 25, (e) Day 32 and (f) Day 39. Note different scales of $y$-axes

obtained in other studies of the same stock (Solbakken 2001, Bang et al. 2006). Our batches may have been poor from the start, possibly due to the young age of some of the parent fish (Table 1), as recruit-spawners can have smaller eggs and less viable offspring than older fish (Blaxter \& Hempel 1963). The small larval size and, hence, small energy reserves, combined with the relatively high temperature and concomitant fast development, could have given the first-feeding larvae insufficient time to learn how to successfully locate and capture prey before the onset of irreversible starvation (Blaxter \& Hempel 1963, Dou et al. 2005).

\section{Starvation resistance}

There was no relation between the time of death and the sagitta size-at-hatch of the larvae from any of the feeding groups (Fig. 4). Under the assumption that sagitta size-at-hatch estimates SMR, mortality was thus not selective with respect to metabolic rate. The use of sagitta size as indicator of SMR is based on several studies on salmonids (Mosegaard et al. 1988, Wright 1991, Yamamoto et al. 1998) and a recent study on zebrafish (Bang \& Grønkjær 2005), which all suggested a significant relationship between SMR and 


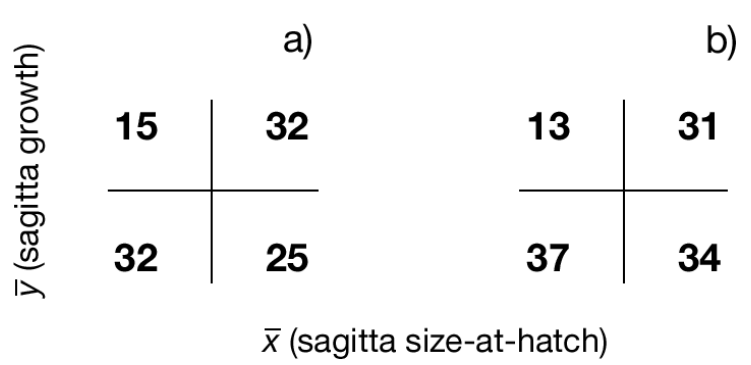

Fig. 7. Clupea harengus. Numbers of larvae from Fig. 6 grouped into 4 quadrants according to mean sagitta sizeat-hatch and mean sagitta growth. All sampling dates are pooled. (a) H1, (b) H2

otolith growth. However, a preliminary experiment suggests that this relationship may be poorer in herring embryos (Bang unpubl.), and potential speciesspecific differences should be investigated further.

The present study does not support the findings of Bochdansky et al. (2005), who found that starving radiated shanny Ulvaria subbifurcata larvae with a relatively small otolith size-at-hatch survived longer than conspecifics with a relatively large otolith size-athatch. This highlights potentially important species differences. Compared to radiated shanny that hatch with a relatively small yolk sac, Atlantic herring larvae hatch with a large yolk sac, which can account for more than half of the total body mass (Blaxter \& Hempel 1963). Obviously, the amount of yolk and, hence, the energy reserves provided at hatch, is also a major determinant of starvation resistance of the individual larva. In the case of the Atlantic herring, variable provisioning of yolk may overshadow differences in the rate at which it is utilised. Because of the large contribution of yolk to the total body mass, the amount of yolk reserves can be approximated by the dry weight of the yolk sac larvae. There was a positive relation between sagitta size and dry weight and almost a $50 \%$ weight difference between the largest and smallest larvae (Fig. 5). The correlation is not based on dry weight data at hatch but on 4 d-old larvae (growth controls); however, prey had not yet been added and weight at Day 4 should thus have been related to weight at hatch. If larvae with a high SMR also have relatively larger energy reserves this could balance the advantage of having a smaller metabolic demand during food shortage, and the 2 groups of larvae would reach irreversible starvation at approximately the same time. A relationship between otolith size and dry weight at hatch is not a generally occurring phenomenon; e.g. in a study on spring-spawning Atlantic herring larvae Høie et al. (1999) found no correlation between sagitta size-at-hatch and larval mass. Furthermore, Bang \& Grønkjæer (2005) found a corre- lation between metabolic rate and otolith size-at-hatch but not between otolith size and larval size-at-hatch in zebrafish. Why such a correlation existed in this study and whether or not it had an influence on the starvation resistance is not clear.

\section{Growth}

Feeding and subsequent growth varied significantly, both between and within the different feeding regimes (Figs. 2 \& 3). Larvae from the H2 group seemed to have had a more successful start-feeding and ended up growing near their maximal potential, while the growth of the H1 group was somewhat suboptimal throughout the experiment. This may have arisen due to small differences in lighting or prey field, or because of a small difference in starting weight and otolith size between the two: at the time of first sampling, larvae from the H1 group weighed significantly less and had significantly smaller otoliths (1-way ANOVA, $\mathrm{p}<$ 0.001) than larvae from all the other groups (data not shown). The feeding ratios (prey larva ${ }^{-1}$ ) could not be corrected for missing larvae or natural mortality of the added zooplankton. However, the 2 sources of error are antagonistic, as the former will underestimate the actual feeding ratio while the latter will overestimate it. The observed trends in feeding ratios and their estimates are, thus, not believed to have been seriously affected. The maximum obtained feeding ratios ( $\mathrm{H} 1$, 0.14 prey larva ${ }^{-1} \mathrm{~min}^{-1}$; H2, 0.56 prey larva ${ }^{-1} \mathrm{~min}^{-1}$ ) compares with the results of a study by Munk \& Kiørboe (1985) who estimated the feeding rate of satiated herring larvae in the laboratory to be 0.23 prey larva $^{-1}$ $\mathrm{min}^{-1}$. The growth rates (Fig. 3) of H2 larvae are comparable to those found in other studies on autumnspawning North Sea herring fed similar high prey levels and experiencing average growth rates of 6.1 to $6.8 \% \mathrm{~d}^{-1}$ (Johannessen et al. 2000, Solbakken 2001). For both groups, the growth parameters responded to feeding in a well-known sequence, in that the otolith growth lagged somewhat being the somatic growth (Folkvord et al. 2000).

Within both high-level feeding larval groups there was a significant tendency for high growth only to be shown by larvae with a large sagitta size-at-hatch (and hence assumed high SMR) (Figs. 6 \& 7). However, there was no significant difference in the number of larvae with a large sagitta size-at-hatch showing high or low growth. So to the extent that sagitta size-athatch reflects metabolic rate, it seems that a high SMR is a prerequisite for fast growth — but having a high SMR does not necessarily entail fast growth. Besides the metabolic rate of the larvae there are many other endogenous factors influencing growth, such as mater- 
nal effects, genetics and the previous growth history of the larva (Jones 2002). Even though the given metabolic rate of a larva may facilitate high growth, other factors may hinder this potential from being fully expressed.

\section{Conclusions}

The present study did not show the estimated SMR of individual herring larvae to have an effect on their starvation resistance - or at least the potential influence was not detectable. It is argued that potential effects of differences in SMR were overshadowed by the variation in the amount of yolk with which the larvae initially hatched. This implies that, in the early life of herring, maternal effects may be a stronger determinant of starvation resistance than metabolic rate. For larvae starving later in life, well after the exhaustion of the yolk sac, the influence of metabolic rate may be stronger and more detectable. After the yolk sac stage no significant investment is made in energy reserves until after metamorphosis, and larvae that are not feeding have been found to be equally susceptible to starving irrespective of age or size (Miller et al. 1988, Jordaan \& Brown 2003). Future studies should focus on the role of metabolic level in determining the starvation resistance of successfully feeding and growing post-yolk sac larvae that are subsequently starved.

On the other hand, the estimated individual SMR was shown to have a significant influence upon the ability of a larva to grow fast. Fast growth enables larvae to quickly outgrow gape-limited predators and larvae growing faster will successively encounter a smaller suite of potential predators. Furthermore, they will attain a larger size-at-age and be less susceptible to threshold mechanisms such as winter mortality (Sogard \& Olla 2000). The decreased stage-duration and larger size-at-age of fast-growing individuals thus yield a fitness advantage over slow-growing individuals. The studied system was without predators and hence did not consider risk-sensitive foraging. If predators were present, the mortality of high SMR larvae might increase because of higher predation associated with riskier foraging necessary to meet their metabolic demands (Munch \& Conover 2003). On the other hand, these fish would have more possibilities to escape from potential predators through increased swimming ability. Whatever the scenario, it is clear that metabolic rate may significantly shape the distribution of survivors in environments with high predation pressure.

Acknowledgements. The authors thank F. Midtøy and J. Skadal for supplying brood fish and for technical assistance during rearing of the herring eggs and larvae. The study was done while A.B. was a Marie Curie Fellow at BATMARE, the Bergen Advanced Training Site for Marine Ecology, European Commission Contract No. EVK3-CT-2000-57129, University of Bergen. The permanent address of A.B. is at the University of Aarhus. Furthermore, the project was supported by a $\mathrm{PhD}$ grant to A.B. from the SLIP research school under the Danish Network for Fisheries and Aquaculture Research financed by the Danish Ministry for Food, Agriculture and Fisheries and the Danish Agricultural and Veterinary Research Council.

\section{LITERATURE CITED}

Álvarez D, Nicieza AG (2005) Is metabolic rate a reliable predictor of growth and survival of brown trout (Salmo trutta) in the wild? Can J Fish Aquat Sci 62:643-649

Arendt JD (1997) Adaptive intrinsic growth rates: an integration across taxa. Q Rev Biol 72:149-177

Bailey KM, Houde ED (1989) Predation on eggs and larvae of marine fishes and the recruitment problem. Adv Mar Biol 25:1-83

Bang A, Grønkjær P (2005) Otolith size-at-hatch reveals embryonic oxygen consumption in the zebrafish, Danio rerio. Mar Biol 147:1419-1423

Bang A, Grønkjær P, Malte H (2004) Individual variation in the rate of oxygen consumption by zebrafish (Danio rerio). J Fish Biol 64:1285-1296

Bang A, Grønkjær P, Clemmesen C, Høie H (2006) Parental effects on early life history traits of Atlantic herring (Clupea harengus L.) larvae. J Exp Mar Biol Ecol 334:51-63

Blaxter JHS, Hempel G (1963) The influence of egg size on herring larvae (Clupea harengus L.). J Cons Perm Int Explor Mer 28:211-240

Blaxter JHS, Hempel G (1966) Utilization of yolk by herring larvae. J Mar Biol Assoc UK 46:219-234

Blaxter JHS, Hunter JR (1982) The biology of the clupeoid fishes. Adv Mar Biol 20:3-223

Blom G, Nordeide JT, Svåsand T, Borge A (1994) Application of two fluorescent chemicals, alizarin complexone and alizarin red S, to mark otoliths of Atlantic cod, Gadus morhua L. Aquacult Fish Manag 25:229-243

Bochdansky AB, Grønkjær P, Herra TP, Leggett WC (2005) Experimental evidence for selection against larvae with high metabolic rates in a food limiting environment. Mar Biol 147:1413-1417

Chambers RC, Leggett WC, Brown JA (1988) Variation in and among early life history traits of laboratory-reared winter flounder Pseudopleuronectes americanus. Mar Ecol Prog Ser 47:1-15

Dou SZ, Masuda R, Tanaka M, Tsukamoto K (2005) Effects of temperature and delayed initial feeding on the survival and growth of Japanese flounder larvae. J Fish Biol 66: 362-377

Ferron A, Leggett WC (1994) An appraisal of condition measures for marine fish larvae. Adv Mar Biol 30:217-303

Folkvord A, Blom G, Johannessen A, Moksness E (2000) Growth-dependent age estimation in herring (Clupea harengus L.) larvae. Fish Res 46:91-103

Hare JA, Cowen RK (1997) Size, growth, development, and survival of the planktonic larvae of Pomatomus saltatrix (Pisces: Pomatomidae). Ecology 78:2415-2431

Høie H, Folkvord A, Johannessen A (1999) Maternal, paternal and temperature effects on otolith size of young herring (Clupea harengus L.) larvae. J Exp Mar Biol Ecol 234: 167-184 
Johannesen A, Blom G, Folkvord A (2000) Differences in growth pattern between spring and autumn spawned herring (Clupea harengus L.). Sarsia 85:461-466

Jones CM (2002) Age and growth. In: Fuiman LA, Werner RG (eds) Fishery science - the unique contributions of early life stages. Blackwell, Bodmin, p 33-63

Jordaan A, Brown JA (2003) The risk on running on empty: the influence of age on starvation and gut fullness in larval Atlantic cod (Gadus morhua). Can J Fish Aquat Sci 60: 1289-1298

McGurk MD (1986) Natural mortality of marine pelagic fish eggs and larvae: role of spatial patchiness. Mar Ecol Prog Ser 34:227-242

Meekan MG, Fortier L (1996) Selection for fast growth during the larval life of Atlantic cod Gadus morhua on the Scotian Shelf. Mar Ecol Prog Ser 137:25-37

Meekan MG, Dodson JJ, Good SP, Ryan DAJ (1998) Otolith and fish size relationships, measurement error, and size-selective mortality during the early life of Atlantic salmon (Salmo salar). Can J Fish Aquat Sci 55:1663-1673

Metcalfe NB, Wright PJ, Thorpe JE (1992) Relationships between social status, otolith size at first feeding and subsequent growth in Atlantic salmon (Salmo salar). J Anim Ecol 61:585-589

Metcalfe NB, Taylor AC, Thorpe JE (1995) Metabolic rate, social status and life-history strategies in Atlantic salmon. Anim Behav 49:431-436

Miller TJ, Crowder LB, Rice JA, Marschall EA (1988) Larval size and recruitment mechanisms in fishes: toward a conceptual framework. Can J Fish Aquat Sci 45: $1657-1670$

Mosegaard H, Svedäng H, Taberman K (1988) Uncoupling of somatic and otolith growth rates in Arctic char (Salvelinus

Editorial responsibility: Jon Hare (Contributing Editor), Narragansett, Rhode Island, USA alpinus) as an effect of differences in temperature response. Can J Fish Aquat Sci 45:1514-1524

Munch SB, Conover DO (2003) Rapid growth results in increased susceptibility to predation in Menidia menidia. Evolution 57:2119-2127

Munk P, Kiørboe T (1985) Feeding behaviour and swimming activity of larval herring (Clupea harengus) in relation to density of copepod nauplii. Mar Ecol Prog Ser 24:15-21

Nathanailides C, Stickland NC (1996) Activity of cytochrome $C$ oxidase and lactate dehydrogenase in muscle tissue of slow growing (lower modal group) and fast growing (upper modal group) Atlantic salmon. J Fish Biol 48: 549-551

Patterson DA, Guderley H, Bouchard P, Macdonald JS, Farrell AP (2004) Maternal influence and population differences in activities of mitochondrial and glycolytic enzymes in emergent sockeye salmon (Oncorhynchus nerka) fry. Can J Fish Aquat Sci 61:1225-1234

Purdom CE (1993) Genetics and fish breeding. Chapman \& Hall, London

Sogard SM, Olla BL (2000) Endurance of simulated winter conditions by age- 0 walleye pollock: effects of body size, water temperature and energy stores. J Fish Biol 56: $1-21$

Solbakken T (2001) Otolittvekst hos larver av høstgytende nordsjøsild (Clupea harengus L.) utsatt for ulik daglengde og næringstilgang. MS thesis, University of Bergen.

Wright PJ (1991) The influence of metabolic rate on otolith increment width in Atlantic salmon parr, Salmo salar L. J Fish Biol 38:929-933

Yamamoto Y, Ueda H, Higashi S (1998) Correlation among dominance status, metabolic rate and otolith size in masu salmon. J Fish Biol 52:281-290

Submitted: August 9, 2005; Accepted: June 15, 2006

Proofs received from author(s): February 1, 2007 